\title{
Rank effects in political promotions
}

\author{
Jaakko Meriläinen ${ }^{1} \cdot$ Janne Tukiainen $^{2,3}$
}

Received: 21 November 2017 / Accepted: 18 July 2018 / Published online: 31 July 2018

(c) The Author(s) 2018

\begin{abstract}
This paper studies the effect of candidates' personal vote ranks on promotions to political power in an open list proportional representation system. Using a regression discontinuity design and data from Finnish local elections, we find that ranking first within a party enhances a politician's chances of getting promoted to the position of a municipal board chair, the most important task in Finnish local politics. Other ranks matter less. We document that the effect of ranking first is larger when there is less within-party competition, but the role of external competition is ambiguous. Our evidence suggests that the mechanism behind the rank effects is primarily unrelated to electoral incentives but rather to party-specific norms or political culture. Ranks seem to be, however, only a complement to other promotion criteria such as politicians' previous political experience or how close to the party lines their policy positions stand.
\end{abstract}

Keywords Open list PR · Political promotions $\cdot$ Preference votes $\cdot$ Rank effects · Regression discontinuity design

JEL Classification C21 · D72

\section{Introduction}

How do political parties select the people who get promoted to leading political positions? The answer is not that obvious and political scientists have been referring to political promotions as the "black box" or "secret garden" of politics (Gallagher and Marsh 1988; Field

Electronic supplementary material The online version of this article (https://doi.org/10.1007/s1112 7-018-0591-8) contains supplementary material, which is available to authorized users.

Jaakko Meriläinen

jaakko.merilainen@iies.su.se

Janne Tukiainen

janne.tukiainen@vatt.fi

1 IIES, Stockholm University, 10691 Stockholm, Sweden

2 Department of Government, London School of Economics and Political Science, Houghton Street, London WC2A 2AE, UK

3 VATT Institute for Economic Research, Arkadiankatu 7, 00101 Helsinki, Finland 
and Siavelis 2008; Hazan and Rahat 2010). Promotions to cabinet or party leadership positions, for example, frequently are considered to be internal matters, and parties may even be reluctant to reveal any details to outsiders.

Many countries around the world use electoral systems with open or semi-open lists in which a voter can or must express her preference for a particular politician amongst the many candidates fielded by a party. Therefore, the outcomes of such elections necessarily reflect voter preferences for individual candidates. This paper studies the extent to which political parties account for voter preferences in the within-party negotiations for political promotions to municipal board and municipal council chairman positions in Finnish local governments. ${ }^{1}$ We analyze the causal effect of intra-party vote ranks on political promotions, and also describe those promotions more broadly. Understanding the links between election outcomes and political promotions is crucial in understanding accountability, how well voter preferences are reflected in actual policies, and how electoral institutions interact with the selection of political leaders when no official rules dictate who becomes a political leader.

Our paper provides several extensions to the literature on rank effects in politics (Crisp et al. 2013; Anagol and Fujiwara 2016; Folke et al. 2016; André et al. 2017). We also contribute to the literature on political selection and the design of electoral systems more generally. First, it is interesting to compare both causal (Folke et al. 2016) and descriptive (Dal Bó et al. 2017) evidence on political promotions in Sweden to our results from Finland, as those countries are otherwise very similar, but differ in electoral systems, with Sweden having a semi-open and Finland a pure open list system. ${ }^{2}$ While the effects of various electoral systems on political behavior have interested political scientists for a long time (Duverger 1954; Grofman and Lijphart 1986; Sartori 1994), comparative evidence on the determinants of political promotions is scarce.

We show that the primary effect-i.e., the effect of ranking first in preferential votes on the likelihood of political promotions (Folke et al. 2016) - is not present in municipalities that are governed by single-party majorities. In other municipalities, (intra-party) election winners are around $20 \%$ more likely to be promoted to the position of municipal board chairman, which is the most important position in Finnish local politics. ${ }^{3}$ It is interesting to observe that parties take individual candidates' vote ranks (rather than vote shares) into account in political promotions. Because our causal findings are based on a regression discontinuity design comparing close winners and close runners-up (Lee and Lemieux 2010), the results imply that in many cases an arbitrary distinction between the candidates may be decisive.

Second, we document three additional novel findings. The effect of ranking first appears to be limited by and large to the highest position of board chairman, as we do not find a statistically significant primary effect on promotions to council chairman, the secondmost important position in Finnish local politics. Furthermore, we do not find any statistically significant evidence that the parties nominating both board and council chairs would

\footnotetext{
1 Throughout the text, we will refer to the nominations to chairman positions simply as "political promotions".

2 A semi-open list is otherwise like a closed list, but voters can affect the ranking by voluntary preferential votes, which jump the candidate to the top of the list if they account for a large enough share of party votes. In a semi-open list, the final ranking is a combination of party and voter choices, whereas in an open list the final ranking is decided solely by the voters.

3 The magnitude of the effect is similar to the Swedish findings, although Folke et al. (2016) do not document similar heterogeneity in the effects.
} 
promote second-ranking candidates to council chairs more often than third-ranking candidates. However, the estimates appear to be positive, economically significant and robust in magnitude across different specifications. Moreover, we find some weak evidence of lower ranks mattering for promotions to council chairmanship.

Third, besides the rank and leadership positions in question, the former may depend on other factors. We find that the primary effect is smaller when internal party competition is stronger. The results regarding the role of external competition are mixed, although most of the evidence supports the argument that the rank effects are larger when the competition between parties is weaker. We also argue that differences in candidate and leadership selection across the political spectrum might influence the primary effect (Duverger 1954; Janda and King 1985; Lisi et al. 2015). Accordingly, we find evidence of rank effects for the rightwing parties, but not for the leftwing parties. This result is supported by evidence from interviews with Finnish party officials. Therefore, party-specific democratic or cultural norms may explain the presence of such effects.

While we do find evidence of the rank effects, the big picture is that ranks seem to have roles complementary to other factors, as the effects are present only in some subsamples. Our descriptive analysis suggests that parties may especially take the candidates' policy positions and their previous political experience into account in their promotion decisions. The latter finding is consistent with the interviews, although the interviewees did not mention policy positions as important determinants of promotions.

\section{Literature review}

Our study is related to several other research efforts. First, rank-based norms or decision rules have been analyzed in various contexts. Some examples documenting such phenomena include Pope (2009), who shows that hospitals that improve their ranking attract more patients in the future, and Hartzmark (2015), who studies rank effects in investors' asset trading behavior.

Second, research has shown that rank-based behavior likewise is present in the political arena. Anagol and Fujiwara (2016) exploit regression discontinuity designs in Brazilian, Indian and Canadian first-past-the-post elections, documenting that second-place candidates are substantially more likely than close third-place candidates to win in subsequent elections. More closely related to our work on how parties make decisions are recent studies by Crisp et al. (2013) and André et al. (2017), who report correlational evidence from Belgium, the Czech Republic and Slovakia, indicating that in the case of semi-open lists, parties reward vote-earning candidates with better future pre-election list positions. Most importantly, Folke et al. (2016) show a causal link between winning the preferential vote and becoming a party leader in Swedish municipalities with semi-open list systems. They label this effect the "primary effect" with the idea that local elections serve the role of primary elections in subsequent intra-party negotiations.

Third, the principles governing intra-party decisions on political promotions and nominations also have been the subject of qualitative research. Of particular interest is the Political Party Database Project, a recent major survey of party organizations in parliamentary and semi-presidential democracies (Poguntke et al. 2016). However, the project focuses on national parties and politics and, thus, does not shed light on how local parties behave.

Fourth, our paper also aims to deepen the understanding of how political parties with different ideologies vary in terms of the selection rules they use. Such differences can be 
found in the form of, for example, gender quotas for candidates (Caul 2001), or different appointment and voting systems (Rahat and Hazan 2001). Among earlier works, Duverger (1954) and Janda and King (1985), for instance, have argued that leftwing parties are more likely to adopt centralized candidate selection processes than right-wing parties are, although the origins of such differences are not entirely clear. However, some scholars, such as Shomer (2014), find weak or no support for party differences in candidate selection procedures. Lisi et al. (2015) use cross-country data over more than half a century to show that parties with different ideologies differ in terms of leadership selection methods across the world. For instance, leftwing parties more often make their leadership choices within party organs than center and rightwing parties do, while center and rightwing parties give the power to voters, party members and conference delegates.

Finally, and more broadly speaking, our results contribute to the literature on political selection (Besley 2005), in particular, how election systems influence political selection (Carey and Shugart 1995; Beath et al. 2016; Braendle 2016) and what personal characteristics are associated with political selection into various offices (Dal Bó et al. 2017).

\section{Theoretical discussion and empirical predictions}

Political parties across the world use different types of rules when they are deciding whom to promote to political power (Poguntke et al. 2016). While Finnish political parties have no official rules dictating who must be promoted, interviews we conducted with party officials suggest that electoral performance is one of the factors that many of the parties consider when determining political promotions. From prior literature (see Sect. 2), we know that decision-makers may base their decisions on rank-based norms or informal rules in various contexts. Why is that the case? We can summarize in the following four points the literature's central arguments.

First, if votes (or vote ranks) matter when parties decide about nominations and promotions, politicians might have stronger incentives to put more effort into their individual campaigns. Such additional effort undoubtedly is desirable from the parties' perspective. Responsiveness to preferences also could be desired by voters (Hopkin 2001; Maravall 2008), not least because they care about policies for which leader identity could be an important determinant (Chattopadhyay and Duflo 2004; Jones and Olken 2005). In the Finnish municipalities, a decisive case in which being chairman matters for policy is a tied vote. The chairman's vote then breaks the tie (both in the board and the council). Moreover, the chairmen of municipal boards and councils often are involved in hiring new public officials. Public officials are considered to have notable power in Finnish municipalities (KAKS 2008). The chairmen can act as political leaders who exploit their high positions to achieve partisan goals. They also can act as democratic leaders who try to promote common goals that have been agreed upon by the majority. In both cases, chairmen could have a considerable impact on policy outcomes.

Second, we can draw an analogy to primary elections in which party members or voters choose the party's candidate. If voters prefer more transparent nomination procedures (Harmel and Janda 1994; Carey and Polga-Hecimovich 2006), the party might be able to attract more votes if those votes matter beyond the immediate election result. Some voter demand for transparent nomination procedures clearly exists in Finnish local politics. For instance, a survey conducted by Kunnallisalan Kehittämissäätiö found that around two out of three voters said that parties should declare their candidates for important political 
positions (KAKS 2008). Furthermore, local newspapers usually write about an election's winners and speculate about nominations. Voters tend to be dissatisfied if the most popular politicians are not given any important positions, which also can be seen in the media. Such voter dissatisfaction might pressure local party groups to give their most popular candidates important positions in the local government.

Third, if any decision rule exists, votes (or vote ranks) would be a simple and objective basis for selection when promotions and nominations are in question.

Fourth, a promotion rule based on vote ranks might be related to internal organization of parties or the party culture. For instance, parties might adopt such a promotion rule to eliminate middle-rank activists or internal conflicts within the party to achieve stronger cohesion (Katz and Mair 1995). Hortala-Vallve and Mueller (2015) theorize that parties introduce primaries when party heterogeneity is too great and parties are in danger of splitting into smaller political groups.

Based on the foregoing arguments, we formulate our main hypothesis as follows:

Hypothesis 1 Parties account for candidates' vote ranks when deciding upon political promotions.

According to Finnish party officials, vote ranks are not the only factor in political promotions. The parties often also base their decisions on candidates' prior political experience and other competencies. Thus, it is plausible not to expect a one-to-one relationship between ranking first, for instance, and being promoted to positions with more political power. We provide descriptive analysis on other determinants of political promotions in Sect. 5.

One party holds more than half of the seats in roughly every third local council. The selection of political leaders may work differently in municipalities governed by singleparty majorities or coalitions. When the largest party has control of over half of the seats, it nominates the board chairman almost without exception (see Table A1 in Online Appendix A). It is possible that inter-party bargaining affects not only which party gets to nominate the leading politicians, but also who these political leaders should be. ${ }^{4}$ Inter-party bargaining and competition may make party behavior more efficient, which potentially means that voters' views are more likely to be internalized in leadership nominations (Folke et al. 2016; Galasso and Nannicini 2011b; De Paola and Scoppa 2011). Thus, we formulate the following hypothesis regarding the difference between municipalities with and without absolute majorities and political competition in general:

Hypothesis 2 The rank effects are larger in coalition governments than in absolute single-party majorities.

Hypothesis 3 The rank effects are larger when external (between-party) competition is more vigorous.

However, the degree of political competition also may have an opposite effect. Hirano and Snyder (2014) argue that primary elections were introduced in the United States to

\footnotetext{
${ }^{4}$ Why municipalities with and without absolute majorities differ from each other also may be related to municipality size or strength of party competition. For a comparison, see Table A2 in Online Appendix A.
} 
promote individual electoral competition within dominant parties in localities where external political competition is weak.

Similar ideas likewise apply to internal political competition. It may be that parties in Finnish local politics adapt a nomination rule based on vote ranks in order to induce more competition within parties when their seats are safe. This leads to the following prediction:

Hypothesis 4 Parties are more likely to use vote ranks as a nomination rule if internal (within-party) political competition for council seats is weak.

Previous research (see Sect. 2) has documented potential differences in candidate selection methods across the political spectrum and, thus, that channel ought not to be neglected when analyzing rank effects. If any ideological differences exist, they may extend to leadership selection. For example, parties may differ in their democratic norms and ideologies or cultures and consequently may adopt different nomination procedures irrespective of how they will be reflected in electoral success. If rightwing parties prefer more inclusive nomination procedures - as found elsewhere (Lisi et al. 2015) as well as in the case of local Finnish politics - then we should expect to find a larger primary effect for them than for leftwing parties. The last hypothesis we postulate and test in this paper is as follows:

Hypothesis 5 The rank effects are larger for candidates from center and rightwing parties than for candidates from leftwing parties.

We interviewed representatives of the eight largest Finnish parties to obtain better understanding of potential partisan differences in political promotion patterns. Those discussions suggest that the differences could indeed arise from different party cultures. For instance, the largest leftwing party is explicit in saying that voters cannot affect promotion choices, whereas other parties say that votes or even vote ranks matter.

\section{Institutional context}

\subsection{Local politics in Finland}

Local governments play an important role in Finland. Decision-making in Finnish municipalities is led by local councils, which are responsible for municipal operations and economic performance. The council appoints a municipal executive board to take decisions and it also can establish committees to deal with specialized governmental functions such as social and healthcare services.

Selection into local political positions is a three-stage process. The first step is open list voting in elections, the second step involves post-election negotiations between parties, and the third step comprises within-party decisions about which individuals are assigned to the governing positions allocated to each party. This paper focuses on the third step.

Municipal councils are elected every fourth year. Finland operates an open list electoral system in which voters cast their votes directly for a single candidate. Voters cannot vote for a party separately from a candidate, but votes also count as votes for the party list to 
which the candidate belongs. ${ }^{5}$ Hence, a vote affects the number of seats a party list can obtain and also ranks the candidate within the party list. Seats on the municipal council are allocated using the D'Hondt method; the total number of seats, varying between 13 and 85 , depends on the town's population. Moreover, seats within political parties are allocated based on candidates' total votes. The municipal elections held between 2000 and 2012 were dominated by three large parties from the political left, center and right, namely, the Social Democratic Party, the Center Party and the National Coalition Party.

\subsection{Rules regarding political promotions}

What is left undecided after the voters cast their ballots is who is promoted to political power in the local government. After the local elections are held, the parties bargain with each other about how to divide the seats on the municipal board and on various committees. Moreover, the parties need to agree on how to share chairmanship positions on the local council, municipal board and committees. The position of municipal board chairman, comparable to a mayor in many other countries, is considered to be the most important post in local politics, while the council chairman is second most important position. ${ }^{6}$ In most cases, the largest party gets to nominate the board chairman and the remaining positions are shared between parties that hold local council seats. ${ }^{7}$ After the parties have agreed on how the important positions in local governance are distributed amongst them, they have to decide whom to nominate to those positions. A majority of the local council members must approve all nominations, but the council typically follows a "gentlemen's agreement" and respects both the intra-party bargaining result and the within-party choices.

Interviews with party officials of the eight largest Finnish parties suggest a large variance in the nomination principles across the parties and even within parties across municipalities; the national party organizations rarely impose any restrictions on promotion decision in local politics. However, half of the parties have adopted national guidelines. We summarize the findings of these interviews in Table 1.

Political promotion decisions are made in practice by both the local party organization (involving party members) and the party's elected councilors. Importantly, the promotion decisions are not in the hands of individual powerful local political leaders. Typically, the decisions are influenced by politicians' electoral performances and competencies, but some parties also consider candidates' prior political experience and gender. Two parties mentioned that either some or many municipalities use an explicit rank rule whereby the one with most votes has first pick of the positions allocated to the party, the second-ranked gets

\footnotetext{
${ }^{5}$ Each candidate is assigned a candidate number that the voter writes on the ballot. Official lists of candidates, their numbers and occupations, ordered by party affiliation, are shown to voters in the voting booth and often published in local newspapers. The order of the parties on these lists is decided by lottery and candidates are listed alphabetically within the party lists.

${ }^{6}$ In a survey conducted in $1996,74 \%$ of local politicians who responded said that the chairmanship of the municipal board is the most desirable position. Moreover, more than two-thirds of the respondents said that the board chairman has more political power than the council chairman (Sinisalmi 1999).

7 Given that the important positions in the local government are distributed proportionally to parties' seat shares and decided by the council, parties sometimes form alliances to increase their bargaining and voting powers (see instructions provided to the municipalities by the Finnish Association of Local Authorities, available online at https://www.kuntaliitto.fi/yleiskirjeet/2012/kunnanhallituksen-lautakuntien-ja-muide n-toimielinten-valinnat; Accessed April 3, 2018). Alliances supply one reason why the largest party does not always get the most important chairmanship.
} 


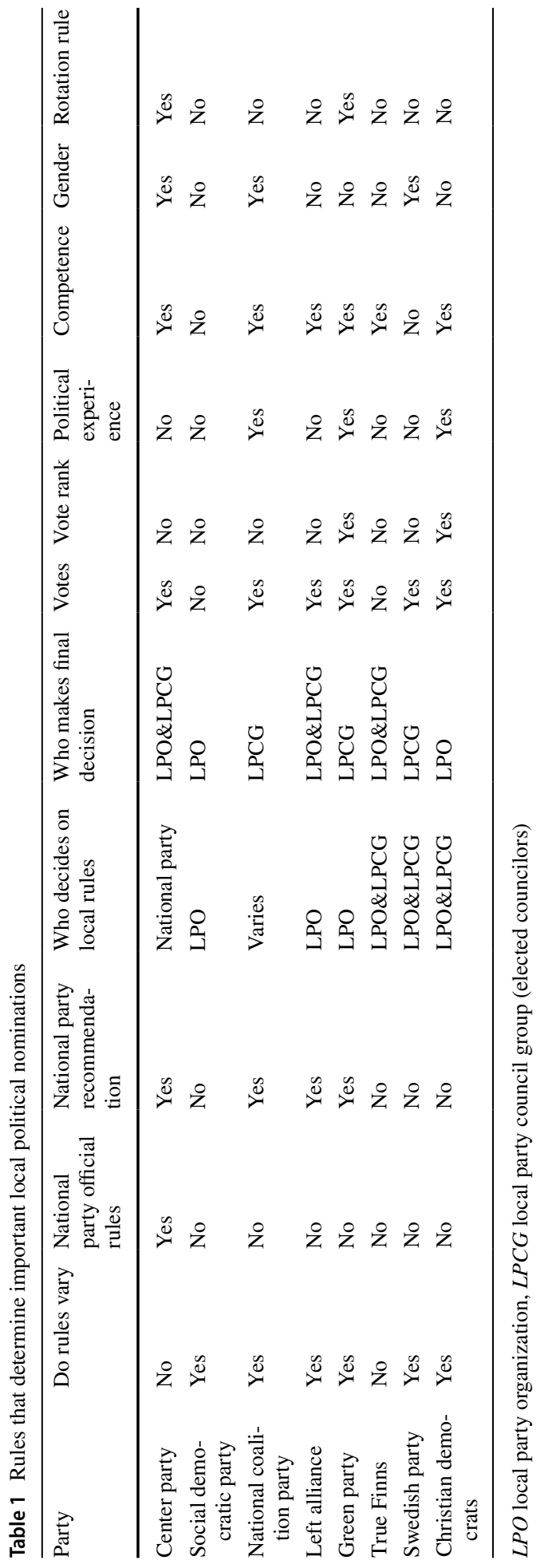


the second pick, and so forth. Four other parties mention that votes influence promotion decisions, but did not mention having a rank-based rule. Two parties do not mention votes mattering at all. Interestingly, the largest leftwing party (the Social Democratic Party) is explicit in saying that voters cannot affect political promotion decisions.

\section{Data and preliminary analysis}

This paper combines municipal election data from the Finnish Ministry of Justice and information on various politicians' local government positions collected by the Association of Finnish Local and Regional Authorities (Kuntaliitto 2013). These data are available for four elections between 2000 and 2012 and the respective electoral terms. The data are further merged with data on municipal employee status from KEVA, income data from the Finnish Tax Administration and socioeconomic characteristics from Statistics Finland.

Three further aspects of the data should be mentioned. First, we omit two municipalities in 2004, as mistakes are evident in their election results. Second, the chairmen are observed at the beginning of each electoral term and some unobserved changes are possible during their 4-year terms in office. For example, parties could agree that a chairman's term is shorter than 4 years and that another person will take his place at some point. Third, chairmen of the municipal boards need not be elected politicians. ${ }^{8}$ We identify 42 such board chairmen in our sample. As they did not participate in elections, we cannot include them in our empirical analysis.

In the main parts of our empirical analysis of rank effects, we enter data only for candidates who rank $n$th and $(n+1)$ th. In a few cases, two (or more) candidates tie in votes and have the same vote rank. We drop such party lists from the sample. We concentrate on the party lists that get to nominate the chairman because the other cases exhibit no variation of interest in the outcome variable. We are interested only in the within-party decisions on who to promote rather than on the between-party allocations of chair positions; thus, the population parameter of interest refers only to the lists that get the chair position.

Table B1 in Online Appendix B provides descriptive comparisons between the winners and runners-up, i.e., the sample used in our main empirical analysis. We notice immediately that the most popular candidates are more likely to obtain important positions in local government than runners-up, but at the same time, they differ along many other dimensions as well. For example, they are more successful in the elections as measured by numbers of votes and vote shares and also more likely to be incumbents, have university educations, have larger earnings and higher socioeconomic status. Such differences indicate that winners could be more competent than runners-up and, hence, more likely to get promoted to top positions for reasons other than their ranks or electoral performances more generally. It is, therefore, likely that they will differ also in many relevant unobservable characteristics, thus calling for a valid research design if we are interested in the causal effect of rank on political promotions.

How do political leaders look compared to other politicians? We turn to that question in Table 2. We show means of various characteristics for four different groups: board chairmen, party list winners, all elected candidates and all candidates. To facilitate the

\footnotetext{
${ }^{8}$ The legislation allows this as the municipal boards are appointed by the council and not elected by the voters (unlike the municipal councils).
} 


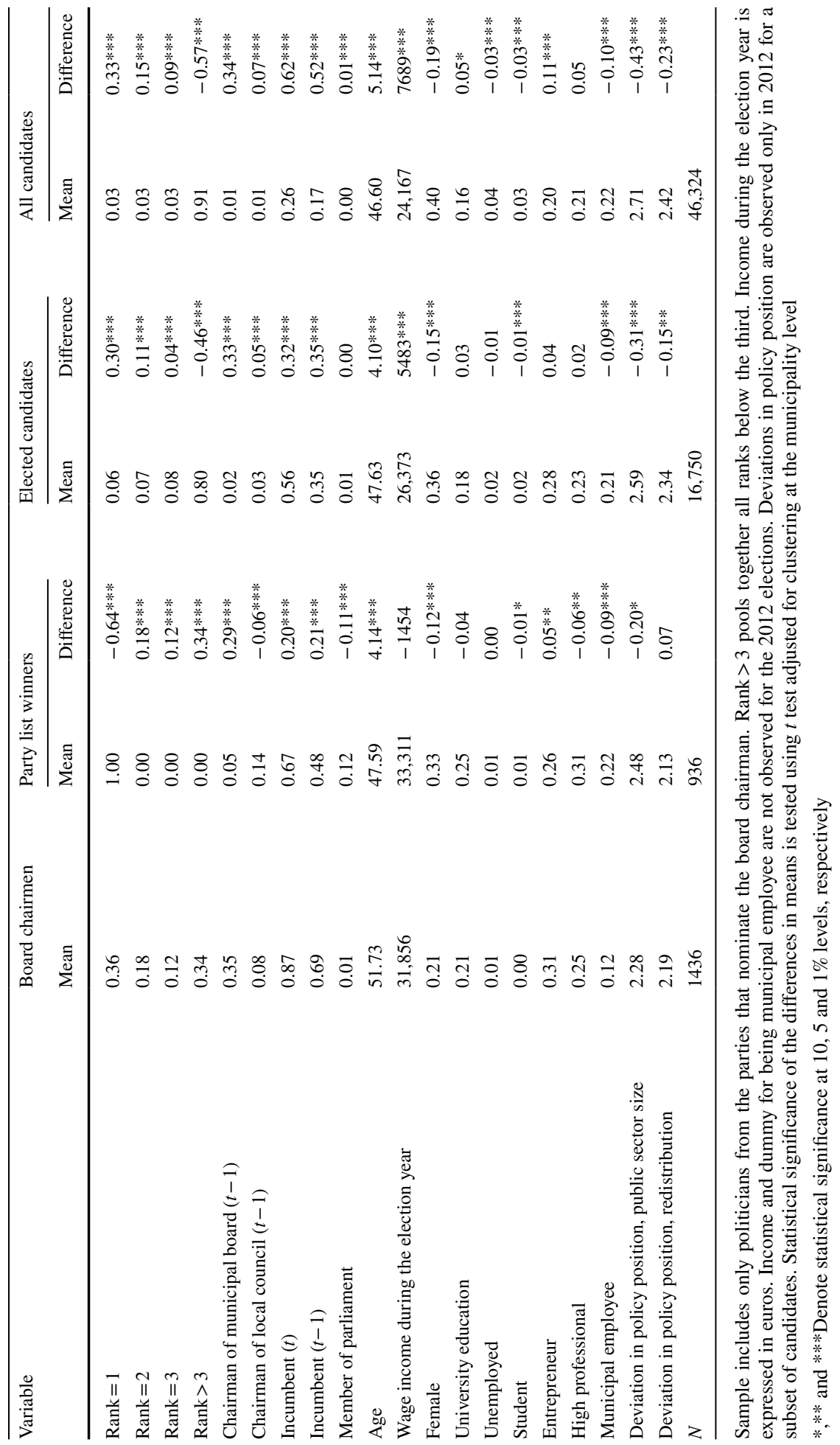


comparison, the latter three groups exclude the board chairs and include only the party lists that got to nominate the board chairman. Note, especially, that the comparison between board chairman and first-ranking politicians provides us with an interesting window for comparing voters' and parties' preferences for politicians.

Several interesting observations arise from those analyses. First, and important for our study, vote rank appears to be (positively) related to becoming a board chairman. That is, however, far from the only dimension along which board chairmen differ. Second, another crucial distinction is that board chairmen are on average more experienced, based on incumbency status, previous leadership experience and age, than candidates in any other group. Third, the chairmen earn more, are less often unemployed and have higher educational attainment than other elected or all candidates. Those comparisons suggest some positive selection into power based on their level of competence to the extent these metrics indicate competence. However, they are less competent than the most popular candidates. Fourth, the share of women among the chairs is much lower than among the election winners, hinting at some possible gender bias in promotions. ${ }^{9}$ Finally, the Finnish parties nominate reliable party leaders whose policy preferences are closer to party averages than those of the other elected politicians, all candidates or the list winners. ${ }^{10}$ These findings are broadly in line with the theoretical arguments of, for example, Crisp et al. (2013) and Tavits (2009) — candidates who accumulate many personal votes are often party outsiders who may disrupt party unity, that is, parties face tradeoffs between popularity and policy cohesion. Bäck et al. (2016) also report related findings. In particular, they show that cabinet ministers are appointed with the aim of minimizing policy distance to the most important political actors.

The findings from the simple mean comparisons largely are corroborated by regression results reported in Online Appendix Tables B2-B4, where we regress a dummy variable for board or council chairmanships on rank dummies and a set of other covariates. Consistent with the idea of vote ranks mattering for political promotions, a higher rank and more votes increase politicians' likelihood of being promoted. Based on that analysis, we would reach conclusions similar to Crisp et al. (2013) and André et al. (2017), namely that all the top ranks matter for political promotions, even after controlling for a rich set of observable characteristics.

To summarize, it seems that parties prefer experience and cohesiveness more than voters, whereas voters have slightly stronger preferences for other metrics, especially competence. Nonetheless, our findings hint that Finnish parties do fairly well in promoting more competent politicians to important positions in the local government. The findings also align with the interviews we conducted with Finnish party officials, according to whom promotion decisions are based mainly on three factors: electoral performance, political experience and other competencies.

More broadly, our descriptive analysis relates to a recent paper by Dal Bó et al. (2017), who study how Swedish local politicians, including political leaders, compare to the populations they represent. They find that local Swedish politicians are on average significantly smarter and are better leaders than the people they represent, measured by test scores on military cognitive and leadership tests. Similarly, leading politicians appear to be more competent than other politicians. The main difference between Finland and Sweden is that in the former voters have more say on who gets elected, while in the latter parties' role

\footnotetext{
9 See also Folke and Rickne (2016), who analyze the glass ceiling in politics.

${ }^{10}$ For detailed description of how these policy indices are constructed, we refer to Online Appendix B.
} 
is more pronounced. Despite these differences, both political systems seem to be able to select elected politician and party leaders who are competent. That conclusion is one indication that semi-open and open lists can be fairly similar in their selection of party leaders.

\section{Empirical strategy}

Simply regressing the outcome, becoming the chairman of a municipal board, on a candidate's vote rank within his party list tells us only something about the correlation between those variables. One central concern is the omission of politicians' characteristics that bias the estimates to an unknown degree and direction. For instance, more able politicians might attract more votes and rank high in election results, but they also could be more likely to receive top positions because of their skills. Such characteristics might be observable to the voter, but not to the econometrician. In order to overcome endogeneity issues in estimating the impact of vote rank on political promotions, we will adopt a regression discontinuity design (RDD) approach.

In the regression discontinuity design (RDD), we compare two candidates with different vote ranks but (almost) the same number of votes, who also are likely to be similar in their characteristics, by estimating regression functions of the form

$$
Y_{\mathrm{it}}=\alpha+\beta \mathbf{1}\left\{v_{\mathrm{it}}>0\right\}+f\left(v_{\mathrm{it}}\right)+\varepsilon_{\mathrm{it}},
$$

where $Y_{\mathrm{it}}$ is the outcome of interest, $v_{\mathrm{it}}$ is the forcing variable measuring the distance from the threshold between two ranks, $\mathbf{1}\left\{v_{\mathrm{it}}>0\right\}$ is an indicator for ranking first and $\beta$ is the coefficient of interest. If $f\left(v_{\mathrm{it}}\right)$ is approximately correctly specified within a given bandwidth, and no precise manipulation of the forcing variable is observed (i.e., the density is smooth at the threshold), the covariates should evolve smoothly at the boundary and, thus, $\hat{\beta}$ will be the causal estimate of the primary effect.

As advised in recent work (Gelman and Imbens 2017), we will execute the design using low-order local polynomial specifications. Our implementation closely follows Hyytinen et al. (2017), who evaluate different implementations of regression discontinuity designs in a close election setting by comparing RDD results with the results from actual randomizations that happen when two (or more) candidates tie for the last seat in Finnish local elections. More specifically, we use local linear and quadratic polynomials estimated separately on both sides of the cutoff. In our benchmark specifications, we employ MSEoptimal bandwidths, but we also verify robustness to alternative bandwidths. ${ }^{11}$ Finally, we also estimate RDD with bias correction and robust inference, as suggested by Calonico et al. (2014). We fix the main and bias bandwidths to be the same following Calonico et al. (2018), who argue that that is an optimal choice. All local regressions use a triangular kernel.

We use the relative vote margin as the forcing variable. For the primary effect regressions, for instance, this is defined as the vote distance of winner (runner-up) from runnerup (winner) divided by the total number of their votes. Doing so means that the threshold between two ranks is set at zero.

Finally, it is not obvious that we will be able to capture any rank effects using RDD that identify a local effect at the threshold where both candidates are equally popular.

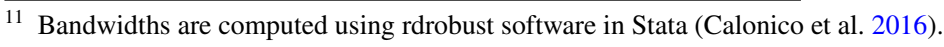


a



b

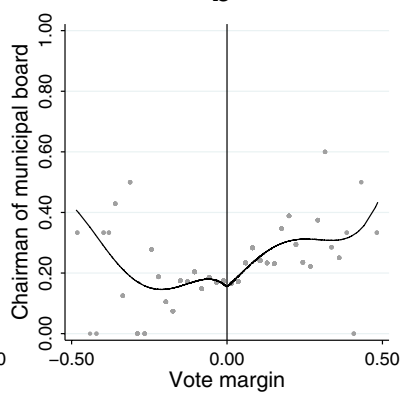

C



Fig. 1 Primary effect on promotions to board chairman. a Full sample, b Absolute majority in municipality, c No absolute majority in municipality

Employing such an empirical strategy necessarily implies that we can identify only the direct and independent effect of vote ranks. The rank effect estimated in that way, if present, requires that rank has relevance up to and above the vote count. Some theories discussed in Sect. 2 do not make a clear distinction between votes and vote ranks. Vote ranks could be more important, for example, if they are more salient indicators of success in elections or voters attach some special value to winning. Previous research has argued that political parties in party-centered environments have incentives to place popular persons high on their electoral lists to maximize their electoral performances (Shugart et al. 2005). Folke et al. (2016) argue that the same logic also should hold for promotions to top positions. Unfortunately, the RDD setting does not allow studying the role of popularity per se. Future work should aim to find alternative strategies for evaluating that aspect.

\section{Primary effect on political nominations}

\subsection{Main results}

To give an overall picture of the data, we plot global polynomials over (almost) the whole range of the running variable. ${ }^{12}$ Figure 1 provides such a graph for the primary effect on promotions to board chairman. It appears that a positive effect of ranking first on being promoted exists, and that the effect comes from municipalities not governed by absolute majorities. Therefore, our results lend support to Hypotheses 1 and 2.

Next, we turn to more detailed regression analysis. In Table 3, we report the estimation results for the primary effect on promotion to board chairman. Column (1) reports the OLS estimates, which do not have a causal interpretation; in columns (2)-(6), we show various RDD results. While the estimates in Panel A are robust across different specifications (different bandwidths and polynomials), they lack statistical significance. That finding turns out to be explained by the fact that the estimates of the primary effect are close to zero in municipalities where the nominating party has an absolute majority (Panel B). Once we

\footnotetext{
12 We use a data-driven approach to choose the bins (see Calonico et al. 2015). More specifically, we use evenly spaced bins that mimic the variance in the data.
} 
Table 3 Estimates of the primary effect on promotions to board chairman

\begin{tabular}{lllllll}
\hline Panel A: Full sample & \multicolumn{7}{l}{} & & & \\
\hline & $(1)$ & $(2)$ & $(3)$ & $(4)$ & $(5)$ & $(6)$ \\
\hline Primary effect & $0.187^{* * * *}$ & 0.105 & 0.075 & 0.107 & 0.091 & $0.107 *$ \\
& {$[0.020]$} & {$[0.069]$} & {$[0.049]$} & {$[0.091]$} & {$[0.062]$} & {$[0.065]$} \\
$N$ & 2704 & 772 & 1388 & 1022 & 1730 & 1388 \\
$R^{2}$ & 0.04 & 0.01 & 0.01 & 0.01 & 0.02 & \\
Bandwidth & & 0.06 & 0.12 & 0.08 & 0.16 & 0.12 \\
\hline
\end{tabular}

Panel B: Absolute majority in municipality

\begin{tabular}{lllllll}
\hline & $(7)$ & $(8)$ & $(9)$ & $(10)$ & $(11)$ & $(12)$ \\
\hline Primary effect & $0.074 * *$ & -0.023 & -0.031 & -0.031 & -0.040 & -0.023 \\
& {$[0.030]$} & {$[0.095]$} & {$[0.066]$} & {$[0.131]$} & {$[0.092]$} & {$[0.095]$} \\
$N$ & 1030 & 292 & 542 & 344 & 644 & 542 \\
$R^{2}$ & 0.01 & 0.00 & 0.01 & 0.00 & 0.01 & \\
Bandwidth & & 0.05 & 0.10 & 0.06 & 0.13 & 0.10 \\
\hline
\end{tabular}

Panel C: No absolute majority in municipality

\begin{tabular}{|c|c|c|c|c|c|c|}
\hline & (13) & (14) & (15) & (16) & (17) & (18) \\
\hline Primary effect & $\begin{array}{l}0.257 * * * \\
{[0.027]}\end{array}$ & $\begin{array}{l}0.214 * * \\
{[0.095]}\end{array}$ & $\begin{array}{l}0.132 * \\
{[0.069]}\end{array}$ & $\begin{array}{l}0.238 * \\
{[0.130]}\end{array}$ & $\begin{array}{l}0.187 * * \\
{[0.091]}\end{array}$ & $\begin{array}{l}0.212 * * \\
{[0.084]}\end{array}$ \\
\hline$N$ & 1674 & 546 & 940 & 650 & 1084 & 940 \\
\hline$R^{2}$ & 0.08 & 0.03 & 0.03 & 0.03 & 0.04 & \\
\hline Bandwidth & & 0.08 & 0.15 & 0.10 & 0.19 & 0.15 \\
\hline$p$ value for difference & & 0.08 & 0.09 & 0.14 & 0.08 & 0.06 \\
\hline Specification & OLS & Local linear & & Local quadratic & & $\begin{array}{l}\text { Local linear } \\
\text { (bias-cor- } \\
\text { rected) }\end{array}$ \\
\hline Bandwidth & & $0.5 * \operatorname{MSE}(1)$ & $\operatorname{MSE}(1)$ & $0.5 * \operatorname{MSE}(2)$ & $\operatorname{MSE}(2)$ & $\operatorname{MSE}(1)$ \\
\hline
\end{tabular}

The outcome is becoming municipal board chairman. The sample includes winners and runners-up from the party nominating the board's chair. Standard errors clustered at the municipality level are shown in brackets; $p$ value refers to testing the difference of the estimates in Panels B and C

$*, * *$ and $* * *$ Denote statistical significance at 10,5 and $1 \%$ levels, respectively

restrict our attention to councils without any absolute majorities (Panel C), we find that the first-ranking candidates are about $13-24 \%$ points more likely to become board chairmen than the runners-up Thus, ranking first versus second roughly doubles the chances of getting a political promotion. These findings support Hypotheses 1 and 2.

In order to evaluate whether the effects estimated for the different subsamples also are statistically distinguishable from one another, we conduct $t$ tests on whether the coefficients for different subsamples are equal. For four out of the five RDD specifications estimating the primary effect, the difference is statistically significant, but only at the $10 \%$ level. Nonetheless, we interpret the evidence as implying a different effect across the subsamples.

Folke et al. (2016) find that in Sweden, 30\% of close runners-up become local political leaders - they are the people most likely to be promoted to mayor if their party gets to fill the 
position at the next election-while the respective share is $60 \%$ for close winners. While the baseline probabilities are larger than what we find in Finnish local councils, the overall effect is very similar in both cases. The similarity of the effect is striking in two ways. First, some political scientists have claimed that semi-open list systems are, in fact, merely closed lists in disguise because voters tend to cast their votes for the candidates placed on top of the list (Farrell 2001; Mueller 2005; Andeweg 2005). However, we find very similar primary effects in the Finnish political context where open lists are used. Second, preferential votes might play a different role in semi-open list elections and open list elections. Our results suggest that that is not the case, either. The result is an important one because electoral rules typically are understood to have substantial influence on political selection in general (Carey and Shugart 1995; Myerson 1999; Besley 2005; Shugart et al. 2005; Galasso and Nannicini 2011a, 2015, 2017).

We report and discuss a rigorous set of validity and robustness checks in Online Appendix C. Those checks support the validity of the empirical design and the robustness of the results that we find.

\subsection{Are parties avoiding voter punishment or following norms?}

We also aim to shed some light on the mechanism through which the rank effects operate. One mechanism that we can test for is that parties might promote winners to political power because they fear that voters would punish them for not doing so. In order to see if that is the case, we estimate the association between not nominating the winner as board chairman after election $t$ and the change in the nominating party's vote share between elections held in $t$ and $t+1$ (measured in percentage points), controlling for municipality, year and party fixed effects. We do not find that the voters would punish the parties if the winner does not get promoted (see Table D1 in Online Appendix D), meaning that the primary effect is not likely to arise from parties' vote-seeking behavior. Therefore, it is more plausible to conclude that some kind of democratic norms underlie the rank effects.

\subsection{Further rank effects}

In Online Appendices D and E, we report an extensive collection of additional rank effect results. First, in Online Appendix D, we explore the effects of lower ranks on promotions to board chairman. No rank effects other than those reported previously are found. Online Appendix E reports the results of analyses similar to those we have seen already, but instead of studying promotions to the chairman of a municipal board, our outcome of interest is becoming the chairman of a municipal council, which is the second most important local political position. We find some evidence of lower ranks mattering for promotions to council chairman. In particular, it appears that ranking 2nd instead of 3rd and 3rd instead of 4th makes promotion more likely. However, those effects - as in the main text-are present only in certain subsamples.

Taken together, our results suggest that the role of vote ranks is rather limited and not as strong as our descriptive analysis would suggest. Furthermore, our results provide a word of caution on what can be learned about rank effects from correlational analysis, such as those presented by Crisp et al. (2013) and André et al. (2017). 


\section{Role of political competition and ideology}

\subsection{Testing hypotheses 3 and 4}

We next turn to a deeper analysis of the role of political competition. Hypotheses 3 and 4 suggest that the rank effect may depend on the degree of political competition, but it is ambiguous as to how those interact with each other. The difference between single-party and coalition-governed local governments provides some support for Hypothesis 3, but further analysis is in order. Folke et al. (2016) provide some empirical evidence for the primary effect being larger in Sweden when political competition is stronger, although they do not distinguish clearly between internal (with-party) and external (between-party) competition. However, internal and external competition may have different implications for rank effects. We employ direct measures of external and internal competition: party seat share Herfindahl-Hirschman index, computed as the sum of squared seat shares, and vote margin within a party for the last seat it receives, respectively. ${ }^{13}$

In the interest of space, we will concentrate on the subsample without absolute majorities and split the remaining sample in two on the basis of the median values of the competition measures. Another rationale for excluding absolute majorities is that the nature of inter-party competition differs widely across such municipalities, which might confound our results. Moreover, not much variation exists along the between-party dimension amongst the absolute majority group. We stress that we cannot provide a causal interpretation as to why the results may differ across the subsamples as we are conditioning on potentially endogenous factors (Fig. 2).

We plot RDD figures for the primary effect in Fig. 3 under four different circumstances: high or low, external or internal competition. The graphs show global quartic polynomials and binned averages. The primary effect appears to be larger when both external and internal competition are weak. That result contradicts Hypothesis 3, but tallies with Hypothesis 4. The findings also align with Hirano and Snyder (2014), who argue that primaries were introduced in the United States to promote individual electoral competition within dominant parties in localities where political competition is weak. Hence, it may be that parties in local Finnish politics adapt a nomination rule based on vote ranks in order to induce more intra-party competition. However, the coefficients generally are not statistically significantly different across the subsamples and, thus, we cannot draw strong conclusions from the results (Table 4). We assess the robustness of the results in Online Appendix F.

We do not find any rank effects in municipalities governed by absolute majorities when the sample is split in two above and below the competition median. Similarly, we do not find rank effects when we use the full sample divided in two by median competition (results not reported).

\footnotetext{
13 We also explored alternative competition measures, i.e., a party's distance from obtaining an absolute majority (external competition) and the ratio of candidates per seats obtained (internal competition). Our findings are robust to using those alternative measures of competition. Note also that our measure of internal competition gauges overall competition within a party rather than competition for the top position. That measure is particularly suitable for testing Hypothesis 4.
} 
a
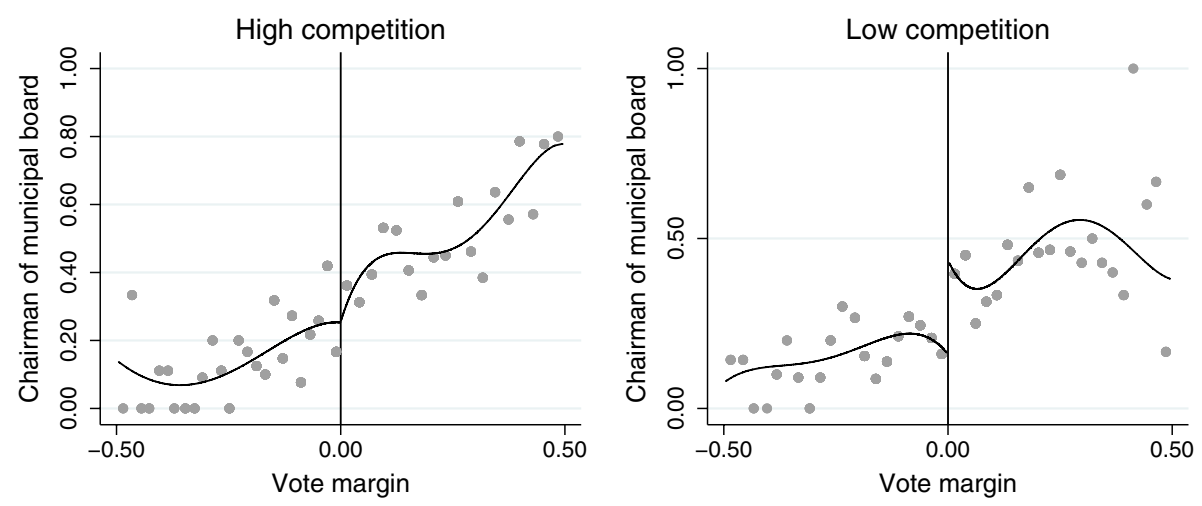

b


Fig. 2 RDD graph, primary effect by competition. a External competition, b Internal competition

a

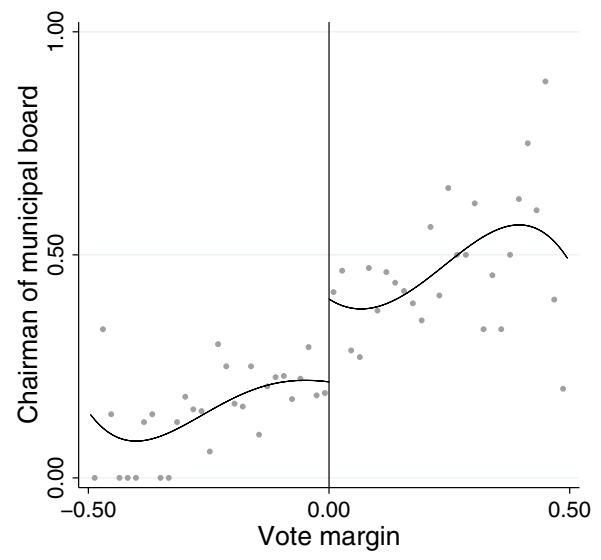

b

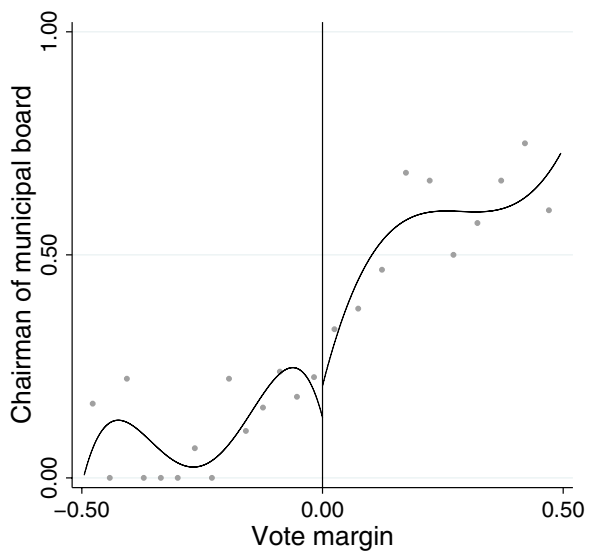

Fig. 3 RDD graph, primary effect by ideology. a Rightwing parties, b Leftwing parties 
Table 4 Primary effect by competition

\begin{tabular}{|c|c|c|c|c|c|c|c|}
\hline \multicolumn{8}{|c|}{ Panel A: External competition } \\
\hline High competition & (1) & (2) & \multicolumn{2}{|l|}{ (3) } & (4) & (5) & (6) \\
\hline Primary effect & $\begin{array}{l}0.286 * * * \\
{[0.038]}\end{array}$ & $\begin{array}{l}0.175 \\
{[0.145]}\end{array}$ & \multicolumn{2}{|c|}{$\begin{array}{l}0.029 \\
{[0.105]}\end{array}$} & $\begin{array}{l}0.213 \\
{[0.169]}\end{array}$ & $\begin{array}{l}0.018 \\
{[0.119]}\end{array}$ & $\begin{array}{l}0.154 \\
{[0.126]}\end{array}$ \\
\hline$N$ & 838 & 220 & \multicolumn{2}{|l|}{384} & 322 & 556 & 384 \\
\hline$R^{2}$ & 0.10 & 0.02 & \multicolumn{2}{|c|}{0.03} & 0.03 & 0.04 & \\
\hline Bandwidth & & 0.07 & \multicolumn{2}{|l|}{0.13} & 0.11 & 0.22 & 0.13 \\
\hline Low competition & (7) & (8) & \multicolumn{2}{|l|}{ (9) } & $(10)$ & (11) & (12) \\
\hline \multirow[t]{2}{*}{ Primary effect } & $0.227 * * *$ & 0.199 & \multicolumn{2}{|c|}{$0.280 * *$} & 0.169 & $0.319 * *$ & $0.321 * * *$ \\
\hline & {$[0.037]$} & [0.177] & \multicolumn{2}{|c|}{$[0.118]$} & {$[0.218]$} & [0.143] & {$[0.117]$} \\
\hline$N$ & 836 & 194 & \multicolumn{2}{|l|}{358} & 294 & 500 & 358 \\
\hline$R^{2}$ & 0.06 & 0.07 & \multicolumn{2}{|l|}{0.05} & 0.06 & 0.04 & \\
\hline Bandwidth & & 0.05 & \multicolumn{2}{|l|}{0.09} & 0.08 & 0.15 & 0.09 \\
\hline $\begin{array}{l}p \text { value for differ- } \\
\text { ence }\end{array}$ & & 0.92 & \multicolumn{2}{|l|}{0.11} & 0.87 & 0.11 & 0.33 \\
\hline \multicolumn{8}{|c|}{ Panel B: Internal competition } \\
\hline High competition & (13) & (14) & \multicolumn{2}{|l|}{ (15) } & (16) & (17) & (18) \\
\hline Primary effect & $\begin{array}{l}0.249 * * * \\
{[0.038]}\end{array}$ & $\begin{array}{l}0.100 \\
{[0.115]}\end{array}$ & \multicolumn{2}{|c|}{$\begin{array}{l}0.095 \\
{[0.090]}\end{array}$} & $\begin{array}{l}0.144 \\
{[0.157]}\end{array}$ & $\begin{array}{l}0.094 \\
{[0.118]}\end{array}$ & $\begin{array}{l}0.101 \\
{[0.104]}\end{array}$ \\
\hline$N$ & 836 & 328 & \multicolumn{2}{|l|}{546} & 350 & 570 & 546 \\
\hline$R^{2}$ & 0.07 & 0.02 & \multicolumn{2}{|c|}{0.03} & 0.03 & 0.03 & \\
\hline Bandwidth & & 0.10 & \multicolumn{2}{|c|}{0.20} & 0.11 & 0.22 & 0.20 \\
\hline Low competition & (19) & $(20)$ & \multicolumn{2}{|l|}{$(21)$} & $(22)$ & (23) & (24) \\
\hline Primary effect & $\begin{array}{l}0.265 * * * \\
{[0.037]}\end{array}$ & $\begin{array}{l}0.316 * * \\
{[0.158]}\end{array}$ & \multicolumn{2}{|c|}{$\begin{array}{l}0.224 * * \\
{[0.113]}\end{array}$} & $\begin{array}{l}0.188 \\
{[0.220]}\end{array}$ & $\begin{array}{l}0.343 * * \\
{[0.153]}\end{array}$ & $\begin{array}{l}0.357 * * \\
{[0.143]}\end{array}$ \\
\hline$N$ & 838 & 226 & \multicolumn{2}{|l|}{406} & 268 & 464 & 546 \\
\hline$R^{2}$ & 0.08 & 0.06 & \multicolumn{2}{|l|}{0.03} & 0.06 & 0.04 & \\
\hline Bandwidth & & 0.06 & \multicolumn{2}{|l|}{0.12} & 0.07 & 0.14 & 0.12 \\
\hline $\begin{array}{l}p \text { value for differ- } \\
\text { ence }\end{array}$ & & 0.27 & \multicolumn{2}{|l|}{0.37} & 0.87 & 0.20 & 0.15 \\
\hline Specification & OLS & Local linear & \multicolumn{3}{|c|}{ Local quadratic } & \multicolumn{2}{|c|}{$\begin{array}{l}\text { Local linear (bias- } \\
\text { corrected) }\end{array}$} \\
\hline Bandwidth & & $0.5 * \operatorname{MSE}(1)$ & $\operatorname{MSE}(1)$ & 0.5 & $\operatorname{MSE}(2)$ & $\operatorname{MSE}(2)$ & \\
\hline
\end{tabular}

The outcome is being chairman of municipal board. Sample includes winners and runners-up from the party nominating the chair. Standard errors clustered at the municipality level are shown in brackets

$*$,** and $* * *$ Denote statistical significance at 10,5 and $1 \%$ levels, respectively

\subsection{Testing hypothesis 5}

Our final hypothesis is that party ideologies matter for the rank effects. To examine whether that is the case, we group the political parties into two blocs and estimate the primary effect for those subsamples. The division between left and right is not strikingly sharp in Finnish 
Table 5 Primary effect by party ideology

\begin{tabular}{|c|c|c|c|c|c|c|}
\hline \multicolumn{7}{|c|}{ Panel A: Rightwing parties } \\
\hline & (1) & (2) & (3) & (4) & (5) & (6) \\
\hline Primary effect & $\begin{array}{l}0.240 * * * \\
{[0.031]}\end{array}$ & $\begin{array}{l}0.282 * * \\
{[0.122]}\end{array}$ & $\begin{array}{l}0.173 * * \\
{[0.084]}\end{array}$ & $\begin{array}{l}0.310 * \\
{[0.174]}\end{array}$ & $\begin{array}{l}0.238 * * \\
{[0.115]}\end{array}$ & $\begin{array}{l}0.282^{* * *} * \\
{[0.106]}\end{array}$ \\
\hline$N$ & 1268 & 432 & 738 & 512 & 852 & 738 \\
\hline$R^{2}$ & 0.07 & 0.04 & 0.03 & 0.04 & 0.04 & \\
\hline Bandwidth & & 0.08 & 0.16 & 0.10 & 0.19 & 0.16 \\
\hline \multicolumn{7}{|c|}{ Panel B: Leftwing parties } \\
\hline & (7) & (8) & (9) & $(10)$ & (11) & (12) \\
\hline Primary effect & $\begin{array}{l}0.333 * * * \\
{[0.052]}\end{array}$ & $\begin{array}{l}0.158 \\
{[0.140]}\end{array}$ & $\begin{array}{l}0.072 \\
{[0.137]}\end{array}$ & $\begin{array}{l}0.244 \\
{[0.177]}\end{array}$ & $\begin{array}{l}0.116 \\
{[0.150]}\end{array}$ & $\begin{array}{l}0.172 \\
{[0.137]}\end{array}$ \\
\hline$N$ & 390 & 102 & 166 & 118 & 214 & 166 \\
\hline$R^{2}$ & 0.13 & 0.07 & 0.03 & 0.09 & 0.05 & \\
\hline Bandwidth & & 0.06 & 0.13 & 0.08 & 0.16 & 0.13 \\
\hline$p$ value for difference & & 0.50 & 0.53 & 0.79 & 0.52 & 0.53 \\
\hline Specification & OLS & Local linear & & Local quadratic & & $\begin{array}{l}\text { Local linear } \\
\text { (bias-cor- } \\
\text { rected) }\end{array}$ \\
\hline Bandwidth & & $0.5 * \operatorname{MSE}(1)$ & $\operatorname{MSE}(1)$ & $0.5 * \operatorname{MSE}(2)$ & $\operatorname{MSE}(2)$ & $\operatorname{MSE}(1)$ \\
\hline
\end{tabular}

The outcome is being chairman of municipal board. Sample includes winners and runners-up from the party nominating the chair. Standard errors clustered at the municipality level are shown in brackets

$* * *$ and $* * *$ Denote statistical significance at 10,5 and $1 \%$ levels, respectively

politics, especially at the local level, but we can provide at least a crude classification based on the bourgeois versus socialist origins of the parties. The parties we assign to the rightwing bloc are the Center Party, the National Coalition Party, True Finns, the Swedish Party and the Christian Democratic Party; the parties assigned to the leftwing bloc are the Social Democratic Party and Left Alliance. ${ }^{14}$ Again, we concentrate on municipalities in which no absolute majority is in power. That choice is natural for facilitating comparison with the results in the previous sections and for the reasons discussed there, but also because almost all of the absolute majority parties would be classified as rightwing.

Figure 3 shows RDD graphs for the primary effect, plotting global quartic polynomials and binned averages. The results for the primary effect provide clear support for Hypothesis 5. We provide further support in Table 5. For the rightwing parties (Panel A), we estimate a statistically significant primary effect of $20-30 \%$ on promotions to board seats, while the estimates for leftwing parties (Panel B) mostly are smaller, less robust and not statistically significant. One caveat, however, is that the number of observations is limited for leftwing

\footnotetext{
14 The results are very similar if we instead divide the parties based on their interview responses (Table 1) relating to whether votes matter for promotions, such that the Social Democratic Party and the True Finns are in one bloc and the other parties constitute the second bloc. The robustness of the results is explained easily because the alternative classification does not change the ideological classifications of the three largest parties which drive the results.
} 
parties and our findings could be explained by the small sample size. We cannot distinguish the estimates statistically from each other for any of the specifications. Moreover, if we include absolute majorities in the estimations, the differences between the political blocs vanish. Additional robustness checks reported in Online Appendix F support the findings.

One potential explanation for the differences in the estimated magnitudes and statistical significances across parties, assuming that they are not just noise, could be that some of the parties could be more policy-oriented and, thus, more likely to choose leaders whose political standing is closer to party ideology, whereas other parties might behave opportunistically and be more prone to cater to voter preferences. In Online Appendix F, we show that this is not the case. While parties are more likely to promote politicians with policy stances closer to party medians, no differences between rightwing and leftwing parties along those lines are evident. Therefore, the fact that the primary effects are larger in magnitude and statistical significance for the rightwing parties is consistent with some party-specific democratic or cultural norms explaining the rank effects (Janda and King 1985; Lisi et al. 2015). Our interview results are consistent with that interpretation.

\section{Conclusions}

This paper explores vote ranks as a determinant of political promotions. While the effects of various electoral systems have long attracted the interest of political scientists (Duverger 1954; Grofman and Lijphart 1986; Sartori 1994), the idea of interaction between the distribution of votes and political appointments recently advocated by Folke et al. (2016) is rather new. We find evidence of the primary effect-i.e., the effect of ranking first in preferential votes within a party - in promotions to chairman of local Finnish municipal boards and some weaker evidence of lower ranks mattering for promotions to the post of council chairman. Moreover, we show that the primary effect differs in the degree of political competition and ideologies of parties.

Because the vote rank is accounted for in the political promotions in only some subsamples, rank is at best complementary to other considerations that parties have in selecting leaders. Our descriptive analysis suggests that politicians' previous political experience and policy positions may play an important role in political promotions.

Our theoretical arguments are general. Thus, they may apply in other electoral contexts or other types of political promotion. It also is plausible that similar empirical patterns could emerge elsewhere. Many countries around the world, such as Austria, the Czech Republic, Denmark, Germany, Indonesia, Japan, Latvia, Spain and Sweden, use open or semi-open lists in at least some of their elections. Furthermore, in many of those countries, local political leaders such as mayors are not elected, but rather appointed from the pool of local councilors. Preferential votes likewise might matter at other levels of government. For instance, the candidates who obtain the most votes in Finnish parliamentary elections"vote rakes" (ääniharava), as they are called in Finnish-often are front-runners when it comes to distributing cabinet positions. Descriptive evidence from a variety of countries (Crisp et al. 2013; André et al. 2017) suggests that much like Finland, the political parties in political systems with preferential voting often choose their vote pullers for political promotion. To what extent such procedures reflect vote ranks and not some other characteristics correlated with electoral success is an empirical question that should be explored further in future research. 
The results of this paper arguably are important from the voters' perspective, as it appears that, under certain circumstances, their votes matter beyond the direct electoral outcomes of their choice on Election Day. Moreover, leading politicians' competencies and qualifications may matter for actual policy outcomes or economic performance (Chattopadhyay and Duflo 2004; Jones and Olken 2005). While evaluating the link between selection of political leaders and policy outcomes is beyond the scope of this paper, it nonetheless is important to understand how leaders are chosen when no explicit rules governing the selection process are in place.

Acknowledgements We thank two anonymous referees, editors William F. Shughart II and Keith Dougherty, Manuel Bagues, Olle Folke, Torsten Persson, Johanna Rickne, Tuukka Saarimaa, Riikka Savolainen, Laura Solanko, David Stadelmann, Marko Terviö, and the audiences at EPSA Brussels, EPCS Freiburg, VATT, Annual Meeting of Finnish Economic Association, IIES-Stockholm University and FDPE Public and Labor Economics Workshop for useful comments and discussions. We are grateful to Emil Aaltonen Foundation for funding.

Open Access This article is distributed under the terms of the Creative Commons Attribution 4.0 International License (http://creativecommons.org/licenses/by/4.0/), which permits unrestricted use, distribution, and reproduction in any medium, provided you give appropriate credit to the original author(s) and the source, provide a link to the Creative Commons license, and indicate if changes were made.

\section{References}

Anagol, S., \& Fujiwara, T. (2016). The runner-up effect. Journal of Political Economy, 124(4), 927-991.

Andeweg, R. (2005). The Netherlands. The sanctity of proportionality. In M. Gallagher \& P. Mitchell (Eds.), The politics of electoral systems. Oxford: Oxford University Press.

André, A., Depauw, S., Shugart, M. S., \& Chytilek, R. (2017). Party nomination strategies in flexible-list systems: Do preference votes matter? Party Politics, 23(5), 589-600.

Bäck, H., Debus, M., \& Müller, W. C. (2016). Intra-party diversity and ministerial selection in coalition governments. Public Choice, 166(3-4), 355-378.

Beath, A., Christia, F., Egorov, G., \& Enikolopov, R. (2016). Electoral rules and political selection: Theory and evidence from a field experiment in Afghanistan. Review of Economic Studies, 83(3), 932-968.

Besley, T. (2005). Political selection. Journal of Economic Perspectives, 19(3), 43-60.

Braendle, T. (2016). Do institutions affect citizens' selection into politics. Journal of Economic Surveys, $30(2), 205-227$.

Calonico, S., Cattaneo, M. D., \& Farrell, M. H. (2018). On the effect of bias estimation on coverage accuracy in nonparametric inference. Journal of the American Statistical Association, 113(522), 767-779.

Calonico, S., Cattaneo, M. D., Farrell, M. F., \& Titiunik, R. (2016). rdrobust: Software for regression-discontinuity designs. Stata Journal, 17(2), 372-404.

Calonico, S., Cattaneo, M. D., \& Titiunik, R. (2014). Robust nonparametric confidence intervals for regression-discontinuity designs. Econometrica, 82(6), 2295-2326.

Calonico, S., Cattaneo, M. D., \& Titiunik, R. (2015). Optimal data-driven regression discontinuity plots. Journal of the American Statistical Association, 110(512), 1753-1769.

Carey, J. M., \& Polga-Hecimovich, J. (2006). Primary elections and candidate strength in Latin America. Journal of Politics, 68, 530-543.

Carey, J. M., \& Shugart, M. S. (1995). Incentives to cultivate a personal vote: A rank ordering of electoral formulas. Electoral Studies, 14(4), 417-439.

Caul, M. (2001). Political parties and the adoption of candidate gender quotas: A cross-national analysis. Journal of Politics, 63(4), 1214-1229.

Chattopadhyay, R., \& Duflo, E. (2004). Women as policy makers: Evidence from a randomized policy experiment in India. Econometrica, 72, 1409-1443.

Crisp, B. F., Olivella, S., Malecki, M., \& Sher, M. (2013). Vote-earning strategies in flexible list systems: Seats at the price of unity. Electoral Studies, 32(4), 658-669.

Dal Bó, E., Finan, F., Folke, O., Persson, T., \& Rickne, J. (2017). Who becomes a politician? Quarterly Journal of Economics, 132(4), 1877-1914. 
De Paola, M., \& Scoppa, V. (2011). Political competition and politician quality: Evidence from Italian municipalities. Public Choice, 148, 547-559.

Duverger, M. (1954). Political parties: Their organization and activity in the modern state. New York: Wiley.

Farrell, D. M. (2001). Electoral systems. A comparative introduction. Basingstoke: Palgrave.

Field, B. N., \& Siavelis, P. M. (2008). Candidate selection procedures in transitional polities: A research note. Party Politics, 14(5), 620-639.

Folke, O., Persson, T., \& Rickne, J. (2016). The primary effect: Preference votes and political promotions. American Political Science Review, 110(3), 559-578.

Folke, O., \& Rickne, J. (2016). The glass ceiling in politics: Formalization and empirical tests. Comparative Political Studies, 49(5), 567-599.

Galasso, V., \& Nannicini, T. (2011a). Electoral rules and politicians' behavior: A micro test. American Economic Journal: Economic Policy, 3(3), 144-174.

Galasso, V., \& Nannicini, T. (2011b). Competing on good politicians. American Political Science Review, 105(1), 79-99.

Galasso, V., \& Nannicini, T. (2015). So closed: Political selection in proportional systems. European Journal of Political Economy, 40, 260-273.

Galasso, V., \& Nannicini, T. (2017). Political selection under alternative electoral rules. Public Choice, 171(3-4), 257-281.

Gallagher, M., \& Marsh, M. (1988). Candidate selection in comparative perspective. The Secret Garden of Politics. London: Sage.

Gelman, A., \& Imbens, G. (2017). Why high-order polynomials should not be used in regression discontinuity designs. Journal of Business and Economic Statistics. (forthcoming).

Grofman, B., \& Lijphart, A. (1986). Electoral laws and their political consequences. New York: Agathon Press.

Harmel, R., \& Janda, K. (1994). An integrated theory of party goals and party change. Journal of Theoretical Politics, 6(3), 259-287.

Hartzmark, S. M. (2015). The worst, the best, ignoring all the rest: The rank effect and trading behavior. Review of Financial Studies, 28(4), 1024-1059.

Hazan, R. Y., \& Rahat, G. (2010). Democracy within parties: Candidate selection methods and their political consequences. Oxford: Oxford University Press.

Hirano, S., \& Snyder, J. M. (2014). Primary elections and the quality of elected officials. Quarterly Journal of Political Science, 9(4), 473-500.

Hopkin, J. (2001). Bringing the members back in? Party Politics, 7(3), 343-361.

Hortala-Vallve, R., \& Mueller, H. (2015). Primaries: The unifying force. Public Choice, 163, $289-305$.

Hyytinen, A., Meriläinen, J., Saarimaa, T., Toivanen, O. \& Tukiainen, J. (2017). When does regression discontinuity design work? Evidence from random election outcomes. Quantitative Economics. (forthcoming).

Janda, K., \& King, D. S. (1985). Formalizing and testing Duverger's theories on political parties. Comparative Political Studies, 18(2), 139-169.

Jones, B. F., \& Olken, B. M. (2005). Do leaders matter? National leadership and growth since World War II. Quarterly Journal of Economics, 120(3), 835-864.

KAKS. (2008). Kansalaismielipide ja kunnat. Ilmapuntari 2008. KAKS Polemia 69.

Katz, R. S., \& Mair, P. (1995). Changing models of party organization and party democracy: The emergence of the cartel party. Party Politics, 1(1), 5-28.

Kuntaliitto. (2013). Kuntien luottamushenkilötilasto.

Lee, D. S., \& Lemieux, T. (2010). Regression discontinuity designs in economics. Journal of Economic Literature, 48, 281-355.

Lisi, M., Freire, A., \& Barberá, O. (2015). Leadership selection methods and party types. In W. Cross \& J.-B. Pillet (Eds.), The politics of party leadership: A cross-national perspective. Oxford: Oxford University Press.

Maravall, J. M. (2008). The political consequences of internal party democracy. In J. M. Maravall \& I. Sánchez-Cuenca (Eds.), Controlling governments: Voters, institutions and accountability. Cambridge: Cambridge University Press.

Mueller, W. (2005). Austria: A complex electoral system with subtle effects. In M. Gallagher \& P. Mitchell(Eds.), The Politics of Electoral Systems. Oxford: Oxford University Press.

Myerson, R. B. (1999). Theoretical comparisons of electoral systems. European Economic Review, 43(4-6), 671-697. 
Poguntke, T., Scarrow, S. E., Webb, P. D., Allern, E. H., Aylott, N., Van Biezen, I., et al. (2016). Party rules, party resources and the politics of parliamentary democracies: How parties organize in the 21st century. Party Politics, 22(6), 661-678.

Pope, D. G. (2009). Reacting to rankings: Evidence from America's best hospitals. Journal of Health Economics, 28(6), 1154-1165.

Rahat, G., \& Hazan, R. Y. (2001). Candidate selection methods. An analytical framework. Party Politics, 7(3), 297-322.

Sartori, G. (1994). Comparative constitutional engineering. Basingstoke: Macmillan.

Shomer, Y. (2014). What affects candidate selection processes? A cross-national examination. Party Politics, 20(4), 533-549.

Shugart, M. S., Suominen, K., \& Valdini, M. E. (2005). Looking for locals: Voter information demands and personal vote-earning attributes of legislators under proportional representation. American Journal of Political Science, 49(2), 437-449.

Sinisalmi, M. (1999). Suomen kaupunkien keskushallinto 1927-1998. Tutkimus kaupunkien keskushallinnon järjestämisestä sekä valtasuhteiden muutoksesta demokratian ja päätöksenteon näkökulmasta. Helsinki: Suomen Kuntaliitto.

Tavits, M. (2009). The making of mavericks: Local loyalties and party defection. Comparative Political Studies, 42(6), 793-815. 